\title{
PERLINDUNGAN HUKUM ATAS VLOG DI YOUTUBE YANG DISIARKAN ULANG OLEH STASIUN TELEVISI TANPA IZIN *
}

\author{
I Made Marta Wijaya** \\ Putu Tuni Cakabawa Landra*** \\ Program Kekhususan Hukum Bisnis \\ Fakultas Hukum Universitas Udayana
}

\begin{abstract}
ABSTRAK
Di era teknologi yang canggih, perkembangan karya cipta sangat beragam dengan kreativitas tinggi banyak mengalamai tindakan plagiarisme dan piracy, salah satunya Vlog. Vlog atau Video Blog merupakan salah satu bentuk karya cipta yang diunggah ke situs YouTube menghasilkan keuntungan. Rumusan masalah dalam artikel ini adalah bagaimana perlindungan karya cipta Vlog yang diunggah ke YouTube dan bagaimana sanksi hukum atas kasus penyiaran ulang Vlog oleh stasiun televisi tanpa izin. Adapun tujuan kajian ini yaitu untuk memahami perlindungan atas karya cipta Vlog yang diunggah ke YouTube dan untuk mengetahui sanksi hukum ketika terjadi penyiaran ulang Vlog oleh stasiun televisi tanpa izin. Metode penelitian dalam penulisan ini adalah metode penelitian hukum normatif dengan pendekatan perundang-undangan dan pendekatan analisis konsep hukum. Hasil dari analisis yaitu bahwa Vlog yang diunggah ke YouTube sebagai bentuk karya cipta dibidang karya sinematografi sejatinya mendapat perlindungan Hak Cipta sebagaimana diatur dalam Pasal 40 ayat (1) huruf $\mathrm{m}$ Undang-Undang Hak Cipta meskipun dalam penjelasan pasal terkait masih menunjukkan norma kabur. Dalam hal Vlog yang disiarkan ulang oleh stasiun televisi tanpa izin mendapat sanksi hukum sebagaimana diatur dalam UU Hak Cipta dengan mengajukan gugatan ganti rugi atau mengadukan sebagai tindak pidana pelanggaran Hak Cipta.
\end{abstract}

\section{Kata Kunci : Hak Cipta, Vlog, YouTube}

\footnotetext{
* Penulisan karya ilmiah yang berjudul Perlindungan Hukum Atas Vlog yang Diunggah ke Channel YouTube (Studi Kasus Penayangan Vlog Awkarin di Televisi) adalah karya ilmiah di luar ringkasan skripsi.

** Penulis pertama dalam karya ilmiah ini ditulis oleh I Made Marta Wijaya adalah mahasiswa Fakultas Hukum Universitas Udayana.

*** Penulis kedua dalam karya ilmiah ini ditulis oleh Dr. Putu Tuni Cakabawa Landra, SH., M.Hum., adalah dosen bagian Hukum Internasional Fakultas Hukum Universitas Udayana.
} 


\begin{abstract}
In the era of sophisticated technology, the development of highly diverse works with high creativity has experienced plagiarism and piracy, one of them is Vlogs. Vlogs or Video Blogs are one form of copyrighted work that uploaded to the YouTube site to get a profit. The problem statement in this article is how to protect the Vlog copyrighted works that uploaded to YouTube and how the legal sanctions for Vlog re-broadcasting cases by television stations without permission. The purpose of this research is to understand the protection of Vlog copyrighted works that uploaded to YouTube and to find out the legal sanctions when television re-broadcasting Vlog without permission. The research method in this paper is a normative legal research method with legal analittical and conseptual approach. The results of the analysis are that the Vlog uploaded to YouTube as a form of copyright in the field of cinematographic works actually gets Copyright protection as stipulated in Article 40 paragraph (1) letter $m$ of the Copyright Act even though the explanation of the relevant article still shows the vague norm. In the case a re-broadcasting Vlogs by television stations without permission, they are subject to legal sanctions as stipulated in the Copyright Act by filing a claim for compensation or complaining as a criminal offense of Copyright infringement.
\end{abstract}

\title{
Key Words : Copyright, Vlog, YouTube
}

\section{PENDAHULUAN}

\subsection{Latar Belakang}

Pesatnya kemajuan teknologi, informasi dan komunikasi dalam era globalisasi ekonomi, telah mendorong perubahan dalam bidang investasi industri dan pemasaran produk. Adanya perubahan ini juga diikuti oleh Hak Kekayaan Intelektual dalam hal ini yang digunakan pada proses pembuatan produk dan pemasarannya. ${ }^{2}$ Sehingga konsep perlindungan saat ini pun tidak hanya pada produk yang telah jadi, tetapi juga pada Hak Kekayaan Intelektualnya. Salah satunya dalam bidang Hak Cipta. Adanya Undang-Undang Republik Indonesia Nomor 28 Tahun

2 Kholis Rosiah, 2015, Konsep Hukum Hak Kekayaan Intelektual, Setara Press, Malang, h. 1. 
2014 Tentang Hak Cipta (selanjutnya disebut UUHC) sebagai payung hukum dalam melindungi berbagai karya cipta atau Ciptaan dari seorang Pencipta. Ciptaan yang dilindungi dalam UUHC merupakan karya kreatif manusia yang bersumber dari intelektualnya baik dalam bidang ilmu pengetahuan, seni dan sastra $^{3}$ sebagaimana diatur dalam Pasal 1 angka 3 UUHC.

Karya cipta yang mendapat perlindungan apabila telah diwujudkan dan harus memiliki bentuk yang khas, bersifat pribadi dan menunjukkan keaslian sebagai bentuk ciptaan yang lahir kemampuan, kreativitas, atau keahlian seseorang. ${ }^{4}$ Salah satu ciptaan yang rawan atas tindakan seperti itu dalam era teknologi dan industri kreatif yaitu karya sinematografi misalnya film. Banyaknya tindak pidana pembajakan membuat Pencipta film menjadi resah untuk menuangkan ide kreatifitas mereka. Bahkan orang yang membajak tersebut tanpa izin mengunggah dan mendapatkan keuntungan dari tindakannya namun merugikan si Pencipta. ${ }^{5}$ Meskipun di dalam UUHC telah diatur mengenai perlindungan hukum atas film sebagai karya sinematografi dalam Pasal 40 ayat (1) huruf m UUHC.

Dalam perkembangan beberapa tahun terakhir muncul ide kreatif dalam bidang karya sinematografi yaitu Video Blog atau disingkat Vlog yang diunggah ke YouTube. Vlog pada mulanya merupakan video dokumentasi aktivitas seseorang untuk koleksi pribadi, namun dalam perkembangannya Vlog dimanfaatkan

3 Ni Ketut Supasti Dharmawan et.al., 2018, Harmonisasi Hukum Kekayaan Intelektual Indonesia, Swasta Nulus, Denpasar, h. 20.

4 Andrian Sutedi, 2013, Hak Atas Kekayaan Intelektual, cet.II, Sinar Grafika, Jakarta, h. 115.

5 Ni Made Rian Ayu Sumardani dan I Made Sarjana, 2018, Perlindungan Hukum Terhadap Pencipta Karya Sinematografi Terkait Pembajakan Film Pada Situs Online, Vol.6 No.3, Kertha Semaya, Fakultas Hukum Universitas Udayana, Denpasar, h. 8 , URL https://ojs.unud.ac.id/index.php/kerthasemaya/article/view/41139, diakses pada tanggal 24 Februari 2019. 
secara khusus oleh publik figur untuk menaikan popularitas dan menambah pendapatan dari kunjungan pengguna YouTube ke Vlog mereka. Sehingga Vlog saat ini memiliki nilai ekonomis yang tinggi di kalangan publik figur pun juga masyarakat luas. Sehingga banyak bermunculan para YouTuber di tanah air.

Selain mendapat keuntungan, tak jarang hal ini membuka kesempatan terjadinya pelanggaran Hak Cipta atas karya cipta Vlog yang diunggah ke YouTube. Hal ini tentu membuat para Pencipta Vlog menjadi resah untuk menuangkan ide dan kreativitasnya ke dalam Vlog di YouTube. Salah satu tindakan pelanggaran atas Vlog yaitu menyiarkan atau mendistrubusikan tanpa izin oleh stasiun televisi yang belaknagan ini sering terjadi. Hal ini tentu menyebabkan kerugian moral maupun ekonomis bagi Pencipta Vlog yang diunggah ke YouTube-nya. Ini dikarenakan adanya kekaburan norma terkait perlindungan hak cipta atas Vlog yang diunggah ke YouTube. Dapat dilihat dalam ketentuan Pasal 40 ayat (1) huruf $m$ bahwa yang mendapat perlindungan hak cipta adalah karya sinematografi.

Dalam penjelasan huruf $\mathrm{m}$ karya sinematografi berupa Ciptaan yang berupa gambar bergerak (moving images) antara lain film dokumenter, film iklan, reportase atau film cerita yang dibuat dengan skenario, dan film kartun. Berdasarkan penjelasan tersebut bahwa karya sinematografi dibatasi hanya dalam bentuk karya film, meskipun pengertian karya sinematografi berupa gambar bergerak dan dapat dipertunjukkan di media lainnya misalnya Vlog yang diunggah ke YouTube pun harus mendapat perlindungan Hak Cipta. Oleh karena itu perlu dianalisis terkait kekaburan norma pada Pasal 40 ayat (1) huruf m sehinga dapat ditentukan sanksi hukum bagi penyiaran ulang Vlog oleh stasiun televisi tanpa seizin Pencipta Vlog. 


\subsection{Rumusan Masalah}

1. Bagaimana perlindungan karya cipta Vlog yang diunggah ke YouTube?

2. Bagaimana sanksi hukum atas kasus penyiaran ulang Vlog oleh stasiun televisi tanpa izin?

\subsection{Tujuan Penulisan}

Adapun tujuan dari kajian ini yaitu untuk memahami perlindungan atas karya cipta Vlog yang diunggah ke YouTube berdasarkan Undang-Undang Hak Cipta dan untuk mengetahui sanksi hukum ketika terjadi pelanggaran Hak Cipta atas Vlog yaitu berupa penyiaran ulang Vlog oleh stasiun televisi tanpa izin seperti yang terjadi pada beberapa kasus di Indonesia.

\section{ISI MAKALAH}

\subsection{Metode Penelitian}

Dalam penelitian ini, adapun jenis penelitian yang digunakan yaitu penelitian hukum normatif. Dengan pendekatan yang digunakan dalam penelitian ini adalah pendekatan Perundang-Undangan (Statue Approach) dalam bidang Hak Cipta dan pendekatan Analisis Konsep Hukum (Analitical \& Conseptual Approach). Penelitian ini bersifat deskriptif dengan menganalisis ketentuan norma yang kabur dalam perlindungan karya cipta Vlog yang dihasilkan oleh Pencipta yang diunggah ke YouTube. Bahan yang digunakan yaitu hukum primer dan bahan hukum sekunder. ${ }^{6}$ Bahan hukum berasal dari bahan hukum primer yakni Undang-Undang Republik Indonesia Nomor 28 Tahun 2014 Tentang Hak Cipta. Untuk bahan hukum sekunder yang digunakan adalah literatur mengenai Hak Cipta dan Perbuatan Melawan Hukum.

6 Amiruddin dan Zainal Asikin, 2016, Pengantar Metode Penelitian Hukum, Cet. IX, PT Raja Grafindo Persada, Jakarta, h. 30. 


\subsection{Hasil dan Pembahasan}

\subsubsection{Perlindungan Karya Cipta Atas Vlog Yang Diunggah Ke YouTube}

Dalam lingkup internasional pengaturan Hak Cipta atau disebut Copyright diatur dalam Berne Convention yang kemudian ditegaskan dalam Perjanjian TRIPs. Pada Perjanjian TRIPs Section 1 Copyright and Related Right spesifiknya pada Article 9 sampai Article 14 menjelaskan mengenai objek-objek ciptaan yang dilindungi berdasarkan TRIPs Agreement. ${ }^{7}$ TRIPs Agreement mempersyaratkan standar minimum yang wajib dipenuhi oleh negara anggotanya dalam rangka perlindungan HKI. TRIPs merupakan suatu perjanjian yang komplek, komprehensif dan ekstensif. ${ }^{8}$ TRIPs dengan standar minimumnya namun (high) wajib menjadi acuan dalam pengaturan HKI di seluruh negara anggota termasuk Indonesia khususnya dalam ranah Hak Cipta.

Bersama dengan kemajuan teknologi dan industri kreatif karya sinematografi pun ikut berkembang salah satunya yaitu Vlog yang diunggah ke Youtube. Ciptaan ini pun tidak dapat terlepas dari permasalahan hukum modern, terutama yang menyangkut pelanggaran Hak Cipta seperti pembajakan konten atau isi video dan penyiaran ulang tanpa izin dari Pencipta. Sehingga penting untuk melindungi hak-hak Pencipta yang berhubungan dengan ciptaannya sebagaimana yang dikatakan dalam UUHC tentang hak eksklusif yang diberikan kepada Pencipta. Pasal 4 UUHC menyatakan bahwa hak eksklusif terdiri

7 Ida Bagus Wyasa dan Ni Ketut Supasti Dharmawan, 2017, Hukum Perdagangan Internasional, Refrika Aditama, Bandung, H. 120-122.

8 Ni Ketut Supasti Dharmawan dan Wayan Wiryawan, 2014, Keberadaan Dan Implikasi Prinsip Mfn Dan Nt Dalam Pengaturan Hak Kekayaan Intelektual Di Indonesia, Vol 6 No.2, Jurnal Magister Hukum Udayana, Magister Hukum, Fakultas Hukum Universitas Udayana, Denpasar, h.262, URL : Https://Ojs.Unud.Ac.Id/Index.Php/Jmhu/Article/View/9463, diakses pada Tanggal 25 Februari 2019. 
atas hak moral dan hak ekonomi. Hak moral merupakan hak yang tidak dapat dialihkan, seperti hak melarang melakukan perubahan terhadap ciptaan. ${ }^{9}$ Hak ekonomi merupakan hak yang dapat dialihkan, seperti hak untuk mengumumkan dan hak untuk memperbanyak. ${ }^{10}$

Hal ini telah diatur dalam UUHC yang mana Hak Ekonomi diatur pada pasal 8 sampai dengan pasal 11 UUHC dan Hak Moral diatur pada pasal 5 ayat (1) UUHC. Merujuk pada aturan tersebut, perlindungan atas hak ekslusif dalam konfigurasi hukum yang mencakup hak moral dan hak ekonomi yang menjamin setiap Pencipta. Hak moral itu sendiri mencakup dua hal utama yaitu right of paternity dan right of integrity. Adapun yang dimaksud dengan right of paternity yaitu hak untuk mencantumkan atau menyebutkan nama Pencipta dalam Ciptaannya sebagaimana terdapat dalam Pasal 5 ayat (1) huruf a dan b UUHC. Sedangkan yang dimaksud dengan right of integrity adalah sikap dan perlakuan terkait integritas atau martabat Pencipta sebagaimana diatur pada Pasal 5 ayat (1) huruf e UUHC.

Lebih lanjut Hak Ekonominya dapat dipahami bahwa hak ekslusif yang dimiliki oleh Pencipta adalah hak untuk mendapatkan manfaat secara ekonomis atas Vlog hanya diperuntukkan baginya sebagai Pencipta Vlog. Pihak lain tidak dapat memanfaatkan hak ekslusif itu tanpa ada perjanjian tertulis untuk mengalihkan Hak Cipta sebagaimana diatur dalam Pasal 16 ayat (2) huruf e. Selain itu, orang lain yang tanpa hak juga tidak diperbolehkan memanfaatkan hak ekslusif atas Ciptaan tanpa izin Pencipta untuk menyiarkan ulang, membuat salinan dan menjualnya ataupun untuk mengimpor dan mengekspor Vlog,

9 Ashibly, 2016, Hukum Hak Cipta (Tinjauan Khusus Forming Right Lagu Indie Berbasis Nilai Keadilan), Yogyakarta, Genta Publishing, h. 27.

10 Ibid. 
serta menampilkan atau memamerkan Ciptaan didepan umum untuk mendapat keuntungan.

Dasar perlindungan Hak Cipta berupa hak eksklusif seperti yang dijelaskan diatas terkait dengan Vlog yang diunggah ke YouTube didasarkan atas ketentuan Pasal 40 ayat (1) huruf m UUHC serta dalam Penjelasan UUHC belum jelas menyatakan bahwa Vlog termasuk karya sinematografi. Hal ini menlihat pada penjelasan huruf $\mathrm{m}$ bahwa karya sinematografi dibatasi antara lain film dokumenter, film iklan, reportase atau film cerita yang dibuat dengan skenario, dan film kartun. Padahal dalam yang dimaksud dengan "karya sinematografi" adalah Ciptaan yang berupa gambar bergerak (moving images) dan Vlog memenuhi pengertian karya sinematografi. Akan tetapi, pembatasan hanya pada karya film menjadikan ketentuan Pasal 40 ayat (1) huruf $m$ menjadi norma kabur sehingga payung hukum perlindungan atas karya cipta Vlog masih kabur. Hal inilah yang menjadi penyebab banyaknya pelanggaran hak cipta atas Vlog terutama terkait penyiaran ulang Vlog oleh stasiun televisi untuk kepentingan komersil dan memperoleh keuntungan ekonomis. Sehingga perlu ditegaskan bahwa Vlog dapat dikategorikan sebagai karya sinematografi merujuk pada pengertian karya sinematografi sebagaimana dijelaskan dalam penjelasan Pasal 40 ayat (1) huruf $\mathrm{m}$ UUHC. Oleh karena adanya perlindungan tersebut, setiap orang atau badan hukum yang ingin melaksanakan hak ekonomi atas Vlog wajib mendapatkan izin Pencipta atau Pemegang Hak Cipta.

Serta setiap orang atau badan hukum yang tanpa izin Pencipta atau Pemegang Hak Cipta dilarang melakukan komersialisasi Vlog baik penyiaran ulang ataupun penggandaan. Sehingga apabila Vlog yang telah diunggah ke YouTube ingin digunakan oleh pihak lain baik itu cuplikan, diimprovisasi, atau 
digabungkan dengan karya lainnya untuk komersialisasi, maka pihak tersebut berkewajiban untuk meminta lisensi. Dalam perjanjian Lisensi akan ditentukan ketentuan untuk membayar royalti sebagai bentuk kontraprestasi atas diberikannya hak ekonomi seorang Pencipta atau Content Creator Vlog tersebut kepada pihak lain untuk penyiaran Vlog baik cuplikan ataupun dalam bentuk penuh.

Selain itu, perlindungan atas Vlog di Youtube sejatinya juga telah mengadopsi Digital Millenium Copyright Act terkait Hak Cipta untuk melindungi konten video Content Creator salah satunya dengan menjaga maupun mengetahui keotentikan sebuah video. Hal ini dilakukan melalui tanda tangan elektronik. Tanda tangan elektronik atau digital dapat memberikan jaminan yang lebih besar terhadap keamanan konten maupun orisinalitas materi yang digunakan. Sehingga Vlog yang telah diunggah dan memiliki tanda tangan digital akan lebih aman dari tindakan pelanggaran Hak Cipta dan lebih mudah pula untuk diketahui bilamana terjadi pelanggaran Hak Cipta.

\subsubsection{Sanksi Hukum Atas Kasus Penyiaran Ulang Vlog oleh Stasiun Televisi Tanpa Izin}

Masih rendahnya tingkat pemahaman masyarakat Indonesia tentang pentingnya perlindungan Hak Cipta menjadi sebab banyaknya kasus pelanggaran Hak Cipta. Selain itu, konsep berpikir masyarakat Indonesia dalam menghargai karya-karya yang lahir dari kemampuan intelektual dengan berbagai pengorbanan serta memiliki nilai ekonomi harus dilindungi ${ }^{11}$ belum sepenuhnya disadari. Sehingga semakin memperbanyak

11 Luh Mas Putri Pricilia dan I Made Subawa, 2018, Akibat Hukum Pengunggahan Karya Cipta Film Tanpa Izin Pencipta di Media Sosial, Vol 06, No. 04, Kertha Semaya, Fakultas Hukum, Universitas Udayana, Denpasar, h. 6. URL: https://ojs.unud.ac.id/index.php/kerthasemaya/article/view/41736 diakses pada tanggal 28 Januari 2019. 
terjadi kasus pelanggaran Hak Cipta di Indonesia yang terjadi pada banyak Pencipta Vlog. Dalam beberapa kasus yang menimpa Pencipta Vlog di Indonesia tersebut terjadi pada suatu program stasiun televisi swasta yang menampilkan cuplikan Vlog salah satu Vloger terkenal yang telah diunggahnya ke YouTube-nya tanpa sepengetahuan dan izin Vloger tersebut. Cuplikan Vlognya disiarkan ulang stasiun televisi untuk diulas oleh para host pembawa acaranya di program tersebut. Penyiaran ini tentunya untuk kepentingan komersil dengan luaran keuntungan yaitu menaikan rating program televisi tersebut.

Kejadian ini pun membuat Vloger tersebut merasa dirugikan baik secara moral dan ekonomi. Sehingga Vloger dalam akun Instagramnya meminta klarifikasi serta pertanggungjawaban pihak stasiun televisi atas tindakan penyiaran ulang cuplikan Vlognya yang dilakukan tanpa seizinnya. Secara hukum Hak Cipta, tentunya hal tersebut merupakan tindakan yang melanggar hak ekslusif Vloger tersebut selaku Pencipta Vlog yang dilindungi negara menurut UUHC. Tindakan yang dilakukan stasiun televisi adalah pelanggaran Hak Cipta sebagaimana diatur dalam Pasal 9 ayat (2) dan ayat (3) UUHC. Di dalam ketentuan pasal tersebut menyebutkan bahwa setiap orang yang menggunakan hak ekonomi sebagaimana dimaksud pada Pasal 9 ayat (1) wajib mendapat izin dari Pencipta/Pemegang Hak Cipta dan dilarang melakukan penggandaan serta penggunaan secara komersil atas Ciptaannya tanpa seizin Pencipta/Pemegang Hak Cipta.

Bahwa tindakan stasiun televisi yang menyiarakan ulang cuplikan Vlog tanpa seizin darinya sudah merupakan suatu pelanggaran Hak Cipta. Pada Pasal 113 ayat (2) UUHC menegaskan bahwa orang yang tanpa hak dan/atau tanpa izin Pencipta/Pemegang Hak Cipta, melakukan pelanggaran hak 
ekonomi Pencipta seperti yang diatur dalam Pasal 9 ayat (1) huruf c, huruf d, huruf $\mathrm{f}$, dan /atau huruf h demi kepentingan komersial, dipidana dengan pidana penjara maksimal tiga tahun dan /atau pidana denda paling banyak Rp. 500.000.000,00. Dalam hal ini, UUHC sebenarnya telah memberikan perlindungan hukum bagi Pencipta Vlog atas karya cipta yang dapat dikategorikan sebagai karya sinematografi dalam bentuk Video Blog merujuk pada ketentuan Pasal 113 ayat (2) UUHC.

Dalam kasus penyiaran Vlog salah satu Vloger ternama oleh stasiun televisi yang digunakan pada dasarnya bukan atas kesepakatan dan tidak ada perjanjian sebelumnya, sehingga tidak ada sesuatu hal yang mengikat diantara keduanya yaitu Pencipta dan pihak stasiun televisi. Hanya saja adanya pelanggaran Hak Cipta karena penayangan cuplikan Vlog tersebut dipergunakan tanpa izin dan tanpa sepengetahuan Penciptanya. Apabila dalam kasus ini, Pencipta Vlog merasa dirugikan atas penggunaan Vlognya tanpa seizin penciptanya selain telah diatur dalam UUHC termasuk tindak pidana Pelanggaran Hak Cipta, juga dapat mengajukan gugatan ke Pengadilan Niaga. Hal ini diatur dalam Pasal 100 UUHC.

Gugatan yang diajukan atas kerugian hak ekonomi yang dialami oleh Pencipta, Pemegang Hak Cipta dan/atau ahli warisnya berhak atas ganti rugi sebagaimana diatur dalam Pasal 96 ayat (1) UUHC. Terlebih lagi dalam kasus ini, pelanggaran yang dilakukan tanpa adanya perjanjian tertulis untuk memberikan hak menyiarkan ulang cuplikan atau seluruh konten Vlognya. Ini dapat diindikasikan sebagai Perbuatan Melawan Hukum (selanjutnya disebut $\mathrm{PMH}$ ) yang diatur dalam Buku II KUHPerdata. Bahwa perbuatan yang dikategorikan sebagai onrechtmatigdaad atau PMH dapat menimbulkan gugatan ganti rugi. 
Hal ini dapat diajukan gugatan ganti rugi jika adanya $\mathrm{PMH}$ terpenuhinya unsur perbuatan melawan hukum, yaitu adanya orang yang melakukan kesalahan dan kesalahan itu menyebabkan orang lain menderita kerugian sebagaimana kententuan Pasal 1365 KUHPerdata. ${ }^{12}$ Dalam kasus penyiaran ulang Vlog oleh stasiun televisi unsur adanya orang yang melakukan kesalahan dan kesalahan tersebut menyebabkan orang lain menderita kerugian telah terpenuhi. Bahwa orang atau subjek hukum yang melakukan kesalahan dalam kasus ini adalah pihak stasiun televisi yang dengan sengaja menggunakan cuplikan Vlog tanpa izin dan sepengetahuan Penciptanya. Kemudian kesalahan yang dilakukan pihak stasiun televisi tersebut menyebabkan kerugian bagi Pencipta baik atas hak moral dan hak ekonominya.

Namun gugatan ganti rugi ini lebih tepat diajukan setelah adanya putusan pidana yang telah memiliki kekuatan hukum tetap. Mengingat bahwa dalam putusan pidana menyatakan bahwa yang bersangkutan memang terbukti melakukan kesalahan. Hal tersebut untuk menjaga keselarasan putusan hakim dalam perkara pidana dan perdata. Sebenarnya dalam amar putusan tentang tindak pidana pelanggaran Hak Cipta, tuntutan ganti rugi atas pelanggaran hak ekonomi Pencipta/Pemegang Hak Cipta dapat diberikan serta dicantumkan sekaligus. Disertai dengan amar putusan untuk membayarkan ganti rugi paling lambat 6 bulan setelah putusan berkekuatan hukum tetap dikeluarkan. Hal ini sesuai dengan ketentuan Pasal 96 ayat (3) UUHC. Perlu diingat pula bahwa bentuk pelanggaran Hak Cipta termasuk delik aduan sebagaimana dalam Pasal 120 UUHC. Sehingga harus dilaporkan oleh orang yang merasa dirugikan untuk dapat diproses apabila memang benar ada h. 81 .

12 Lukman Santoso AZ, 2016, Hukum Perikatan, Setara Press, Malang, 
pengaduan pihak yang dirugikan.

Untuk menghindari adanya tuntutan pidana dan/atau gugatan ganti rugi serta agar tidak terjadi kembali kasus serupa, perlu adanya tindakan preventif. Tindakan ini dapat dilakukan dengan cara meminta lisensi oleh pihak stasiun televisi ingin menggunakan Vlog yang diunggah ke YouTube dalam programnya untuk kepentingan komersil. Dengan meminta izin tertulis dari Pencipta Vlog yang biasa disebut lisensi untuk menggunakan konten Vlognya baik seluruh atau sebagian, maka terjadi hubungan kerjasama dengan adanya pemberian royalti kepada Pencipta/Content Creator.

\section{PENUTUP}

\subsection{Kesimpulan}

1. Perlindungan karya cipta Vlog yang diunggah ke YouTube dapat dikategorikan sebagai karya sinematografi sesuai dengan penjelasan Pasal 40 ayat (1) huruf $m$ yang dilindungi Hak Cipta meskipun ketentuan normanya masih kabur dengan pembatasan bentuk karya sinematografi hanya dalam bentuk film sebagaimana penjelasan Pasal 40 ayat (1) huruf $\mathrm{m}$.

2. Sanksi hukum atas kasus penyiaran ulang Vlog oleh stasiun televisi tanpa izin yaitu dapat digugat atas pelanggaran Hak Cipta ke Pengadilan Niaga sebagaimana diatur dalam Pasal 100 UUHC atau melaporkan terkait adanya pelanggaran Hak Cipta sebagaimana diatur dalam Pasal 120 UUHC dengan ancaman pidana sebagaimana diatur dalam Pasal 113 ayat (2) UUHC.

\subsection{Saran}

1. Diharapkan bagi pembentuk undang-undang untuk melakukan revisi ataupun memperjelas kembali dan/atau 
melengkapi norma yang masih kabur berkaitan dengan jenis dan bentuk karya sinematografi yang dilindungi oleh UU Hak Cipta khususnya Vlog. Mengingat kreativitas dibidang ini akan selalu berkembang dan agar mencegh terjadinya pelanggaran atas pemanfaatan atau penggunaan karya cipta Vlog yang diunggah ke YouTube.

2. Diharapkan tiap-tiap stasiun televisi lebih dispilin dalam menyangkan segala sesuatu dalam suatu program yang bertujuan komersil agar tidak lagi melakukan pelanggaran Hak Cipta atas karya Vlog dan dapat melakukan perjanjian tertulis dengan Pencipta Vlog mengenai penyiaran ulang Vlog oleh stasiun televisi dalam acaranya.

\section{DAFTAR PUSTAKA}

\section{Buku-Buku :}

Amiruddin dan Zainal Asikin, 2016, Pengantar Metode Penelitian Hukum, Cet. IX, PT Raja Grafindo Persada, Jakarta.

Ashibly, 2016, Hukum Hak Cipta (Tinjauan Khusus Forming Right Lagu Indie Berbasis Nilai Keadilan), Yogyakarta, Genta Publishing.

AZ, Lukman Santoso, 2016, Hukum Perikatan, Setara Press, Malang.

Dharmawan, Ni Ketut Supasti et.al., 2018, Harmonisasi Hukum Kekayaan Intelektual Indonesia, Swasta Nulus, Denpasar.

Rosiah, Kholis, 2015, Konsep Hukum Hak Kekayaan Intelektual, Setara Press, Malang.

Soelistyo, Henry, 2011, Hak Cipta Tanpa Hak Moral, PT. Raja Grafindo Persada, Jakarta.

Sutedi, Andrian, 2013, Hak Atas Kekayaan Intelektual, cet.II, Sinar Grafika, Jakarta. 
Wyasa, Ida Bagus dan Ni Ketut Supasti Dharmawan, 2017, Hukum Perdagangan Internasional, Refrika Aditama, Bandung.

\section{Jurnal Ilmiah :}

Dharmawan, Ni Ketut Supasti dan Wayan Wiryawan, 2014, Keberadaan Dan Implikasi Prinsip Mfn Dan Nt Dalam Pengaturan Hak Kekayaan Intelektual Di Indonesia, Vol 6 No.2, Jurnal Magister Hukum Udayana, Magister Hukum, Fakultas Hukum Universitas Udayana, Denpasar.

Pricilia, Luh Mas Putri dan I Made Subawa, 2018, Akibat Hukum Pengunggahan Karya Cipta Film Tanpa Izin Pencipta di Media Sosial, Vol 06, No. 04, Kertha Semaya, Fakultas Hukum, Universitas Udayana, Denpasar.

Sumardani, Ni Made Rian Ayu dan I Made Sarjana, 2018, Perlindungan Hukum Terhadap Pencipta Karya Sinematografi Terkait Pembajakan Film Pada Situs Online, Vol.6 No.3, Kertha Semaya, Fakultas Hukum Universitas Udayana, Denpasar.

Stefano, Daniel Andre, Hendro Saptono, dan Siti Mahmudah, 2016, Perlindungan Hukum Pemegang Hak Cipta Film Terhadap Pelanggaran Hak Cipta Yang Dilakukan Situs Penyedia Layanan Film Steaming Gratis di Internet (Menurut Undang-Undang Nomor 28 Tahun 2014 Tentang Hak Cipta), Volume 5, Nomor 3, Diponegoro Law Journal, Fakultas Hukum, Universitas Diponegoro, Semarang.

\section{Peraturan Perundang-Undangan:}

Republik Indonesia, 2014, Undang-Undang Nomor 28 Tahun 2014 tentang Hak Cipta, Lembaran Negara Republik Indonesia Tahun 2014, Nomor 266, Tambahan Lembaran Negara Nomor 5599, Menteri Hukum dan Hak Asasi Manusia, Jakarta. 